\title{
Chapter 1 \\ FOUNDING THOUGHTS: ADAM SMITH, CAPITALISM, AND ISLAMIC FINANCE
}

\section{Topics in this Chapter}

1.1 The Roots: The Economy, Real and Financial Sectors, Risk and Islamic Finance

1.2 Uncertainty and Risk

1.3 Why Do Uncertainty and Risk Exist?

1.4 Types of Risk

1.5 Risk in Real and Financial Sectors

1.6 Financial System of Capitalism: The Foundations

1.7 Smith and Arrow

1.8 Smith and Ethical Rules

1.9 An Arrow-Debreu Economy

1.10 What Happened to Smith-Arrow Risk-Sharing Ideal?

1.11 Can Economics Explain a Positive Predetermined Rate of Interest?

1.12 Islamic Finance: The Foundations

1.13 Islamic Rules Governing Exchange

1.14 Islamic Financial Market and Instruments

1.15 Islamic Finance Industry at the Present

\section{Chapter Objective}

This chapter is designed to introduce students to the conceptual basics of the linkage between the real and financial sectors. On completing this chapter, you should have a good understanding of the framework and theory of capitalism and a comparative understanding of the foundations of Islamic financial system

\begin{tabular}{ccc} 
& Key Terms & \\
\hline Arrow-Debreu model & globalization & real sector \\
\hline capitalism & intermediation & risk-sharing \\
\hline complete contracts & invisible hand & Theory of Moral Sentiments \\
\hline complete markets & markets and exchange & transparency \\
\hline contracts and trusts & property rights & uncertainty and risks \\
\hline financial sector & Qur'an and Sunnah & \\
\hline
\end{tabular}




\subsection{The Roots: The Economy, Real and Financial Sectors, Risk and Islamic Finance}

This book is about capital markets, a vital part of any economy. As Chapter 2 explains, an economy can be thought of as being composed of a real sector and a financial sector. The former is where goods and services are produced. The financial sector, on the other hand, facilitates real sector activities through provision of financing.

In any society, there are "surplus units", i.e., those who save surpluses remaining from their income after expenditures. There are also those who are "deficit units" in the sense that they are either spending more than the income they earn or are in need of funds to complete or initiate projects in the real sector of the economy. The important function of the financial sector of an economy is to act as an intermediate between these surplus and deficit units. It does so by providing short-term funds in the money market and medium-to-long-term funds through the capital market. In effect, the financial sector allows the surplus units to postpone their expenditure plans while making it possible for the deficit units to bring their expenditure plans forward. Both do so through the money and capital markets.

Up to the 1970s, the primary function of capital markets was to act as an intermediate for surplus funds by channeling them to investment, i.e., to create additional capital (capital formation) in the real sector of the economy. This, in turn, created additional employment and income. This is the economic understanding of the concept of investment. In day-to-day conversation, however, the word "investment" refers to purchases of any asset instrument that represents a flow of future income. For example, it may refer to purchases of already existing bonds or shares of stocks. This is not an investment in the economic sense but a transfer of ownership of existing assets, a process that does not necessarily lead to creating additional productive capacity and, thereby, additional employment and income.

Since the 1980s, much of the growth of capital markets has been attributed to a rapid increase in the latter types of transactions to the point that only a very small portion of the large volume of transactions in capital markets end up in new capital formation. In fact, a famous innovator and major market participant calls this type of ownership transfer "speculation", and considers that there is now a "clash of cultures" of investment and speculation in the market (Bogle, 2012). The difference between the two is that investment expands capital formation and increases employment and income, but speculation does not. Investment increases the income of the investor, jobholders, and households, while speculation increases the income of the asset holders (usually the rich).

What has become painfully clear during the post-2007/2008 financial crisis is that how well a financial sector performs its primary function of intermediation determines the stability of the financial sector and, consequently, that of the entire economy. Many economists believe that a major underlying cause of the crisis was that the relation between finance and real sector activities has become increasingly weakened in the last four decades. ${ }^{1}$ Financial sector has grown much more rapidly than the real sector and has taken a life of its own; the sectors have decoupled. This phenomenon, driven by speculation, is referred to as financialization of the economy. ${ }^{2}$ A crucial auxiliary function of the financial sector is to provide ways and means by which members of the society manage financial risks they face. Instruments developed in the financial sector are designed to perform this function. An understanding of risk is elemental to comprehending the role and functioning of the financial sector.

\subsection{Uncertainty and Risk}

Decision-making is one of the most fundamental capabilities of humans. Actions follow decisions. Individuals have to make decisions and take actions that affect their own as well as others' lives at some point in the future. However, the future is, for the most part, unknown, and therefore unpredictable and uncertain. Uncertainty is a fact of human existence as we all live on the brink of a future about which our information is dominated by ignorance. Facing an unknown and often unknowable future, individuals still have to make decisions and take actions. This they do by forming expectations about the payoffs to alternative courses of action.

Expectations can be formed by individuals objectively or subjectively. In the first case, the expected payoffs are based on known probability techniques, as in the insurance industry. Alternatively, individuals can base their expectations of payoffs to alternative decisions based on their own or others' personal experiences. Either way the 
expected outcomes will form expressions in terms of the probability of occurrences of the consequences of actions. Through this process, uncertainty is converted to risk. Therefore, risk is a consequence of choice under uncertainty. It is uncertainty about the future that makes human lives prone to risk.

Risk would arise because the decision-maker has little to no information regarding which state of affairs will materialize in the future. The individual nevertheless makes a decision and takes appropriate action based on expectations. Risk can also arise because the decision-maker does not or cannot consider all possible states or outcomes that may prevail in the future. There may be so much missing information that it is impossible to form expectations about payoffs to decisions and actions. This situation is referred to as ambiguity, which may lead to paralysis in decision-making. One way of dealing with ambiguity caused by missing information is patience; postponing decisions until more information becomes available.

\subsection{Why Do Uncertainty and Risk Exist?}

How can uncertainty and its overwhelming influence in human life be explained? Why is life subjected to so much uncertainty? These are particularly significant questions for those believing in "intelligent design" or in a Supreme Creator. Why is uncertainty created for humans? Bartholomeu (2008, p. 230) suggests that "risk is a necessary ingredient for full human development. It provides the richness and diversity of experience necessary to develop our skills and personalities". Moreover, he argues (2008, p. 200, p. 239) that the "development of human freedom requires that there be sufficient space for that freedom to be exercised. Chance seems to provide just the flexibility required and freedom; risk is the price we pay for freedom".

Similar reasoning is clearly discernible from the Qur'an. Freedom is a crucial characteristic of human dignity bestowed by the Supreme Creator. The right path, and the rules of traversing it, is prescribed and differentiated from the wrong path. It is then left to humans' freedom of choice to make decisions as part of their rights and responsibilities. Uncertainty and risk exist to allow humans to learn as they are confronted with choices. This process is termed "testing" in the Qur'an. Humans choose under uncertainty. Their choices determine the consequences. Confronted with a choice, they are tested as to the path they select. The test is whether or not they choose to act in accordance with rules prescribed by their Creator.

Clearly, individuals exercise their freedom in choosing to comply with these rules. In a number of verses, the Qur'an asserts that life on this earth is temporary. As such, it is a crucible of constant testing, trials, and tribulations (see, e.g., Verse 155, Chapter 2 and Verse 2, Chapter 76). Not even the believers are spared testing. In Verse 2 of Chapter 29 the Qur' an asks: "Do humans think that they will be left alone when they say: we believe, and they therefore will not be tested?" To every test, trial, and tribulation in their lives, humans respond, and in doing so, they demonstrate a measure self-awareness and consciousness of their Creator. If the response-action is in compliance with the rules prescribed by the Creator, then the test becomes an occasion for self-development and strengthens consciousness of the Creator. All actions are risky because the full spectrum of future consequences of actions, within the horizon of birth to eternity, is not known with certainty. As the Qur' an asserts “... at times you may dislike a thing when it is good for you and at times you like a thing and it is bad for you. Allah knows and you do not" (Verse 216, Chapter 2). In short, human life here is a time to be tested, and to learn and develop through the exercise of freedom of choice granted to humans by their Creator. Crucially, testing is not possible without risk and uncertainty.

\subsection{Types of Risk}

Individuals in any society face two types of risk. The first is systemic, the result of the exposure of the economy to uncertainty and risk due to external and internal economic circumstances of the society and its vulnerabilities to shocks. How well an economy will absorb shocks depends on its resilience, which depends on the institutional and policy infrastructure of risk management in the society. How flexibly the infrastructure will respond to shocks will determine how much this type of risk impacts individual lives when it materializes. 
The second type of risk individuals face relates to the circumstances of their own lives. These include risk of injuries, illness, accidents, bankruptcies, or even change in tastes and preferences. This kind of risk is referred to as idiosyncratic, and when it materializes, they play havoc with people's livelihoods. This is because people's livelihoods, and therefore their consumption levels, often depend directly on their income. If income becomes volatile, so will their livelihoods and consumption levels. Participation in capital market activities can help mitigate idiosyncratic risk by diversifying the source of income. Capital market instruments, when purchased by individuals, reduce the correlation between income and consumption and strengthen the resilience of their lives to idiosyncratic shocks. Thus, when shocks reduce income, consumption levels of the individuals invested in capital market need not suffer.

\subsection{Risk in Real and Financial Sectors}

As mentioned earlier, there are two major sectors in the economy. The real sector is where goods and services are produced. ${ }^{3}$ Until very recently, the major function of the financial sector was to facilitate the financing of projects. The decision to take risks to produce a product precedes the decision on what to do with the risk in financing the project. Once the decision to undertake a project in the real sector is made, a subsequent decision has to be made as to the mode of financing. The risk taken in the real sector has to consider risks associated with the business end of the project. The firm or the entrepreneur can finance the project from their own sources or seek external financing. The risk of financing can be transferred, shifted, or shared. Figure 1.1 shows how risks that originate in the real sector get transferred, shifted, or shared in the financial sector.

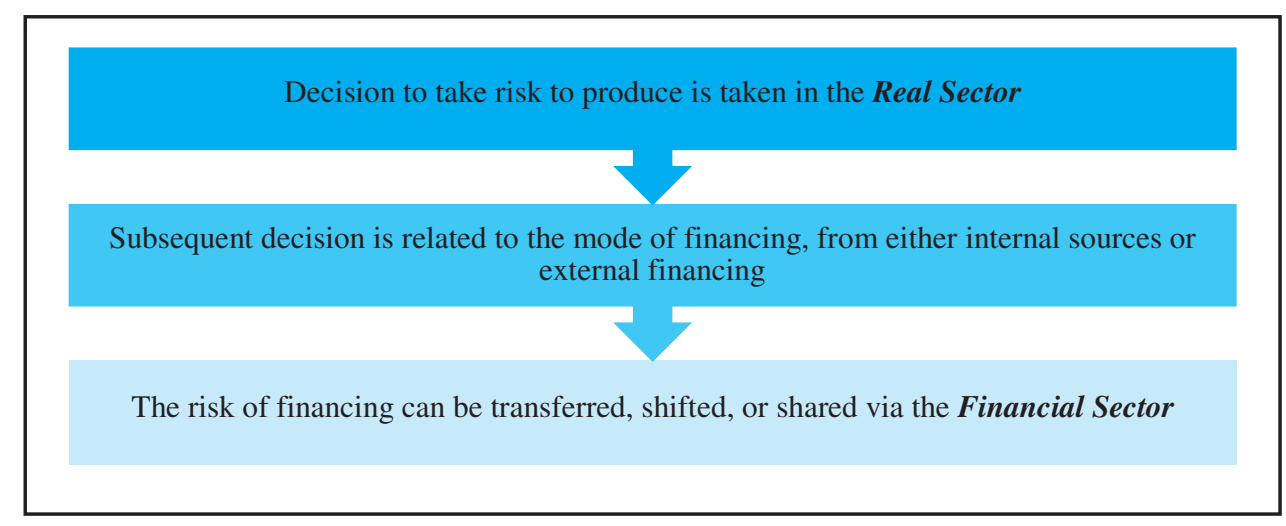

Figure 1.1. Risk in the Real Sector and in the Financial Sector.

Risk of financing is transferred when a trusted intermediary makes the surplus funds of savers available to the deficit units seeking funds for their project; the intermediary is trusted to know the borrowers well enough, by undertaking due diligence, to know that they could be trusted or obtain strong enough collateral to protect the funds. Finance risk is thus transferred from the surplus units to deficit units through the intermediation of the financial sector. Until the 1980s, the main function of commercial banks was risk transfer, where private sector's savings were channeled to finance real sector's activities. Risk of a financial (or real) transaction may be shifted to a third party that is not directly involved in the transaction without its knowledge or consent. An example of risk-shifting in the real sector is environmental pollution, whose costs are shifted to the society without its prior knowledge or consent. An example of risk-shifting in the financial sector is the financial trading prior to the crisis of 2007/2008 that shifted risk ultimately to the taxpayers who were unaware they were bearing the risk of the financial sector. Risk is shared when each party to a transaction carries business and finance risk in accordance to their ability to bear such risk. 


\subsection{Financial System of Capitalism: The Foundations}

From the time of formal inception of contemporary capitalism until the second half of the 20th century, intermediation between surplus and deficit units in support of real sector activities was considered the most important function of the finance sector. As mentioned earlier, this is a framework for risk transfer. Virtually all supervisory and regulatory infrastructure of the financial sector was designed within the framework of risk transfer. The 2007/2008 crisis, however, demonstrated how easily and rapidly a system operating within a framework of risk transfer can switch into risk-shifting. Many scholars consider that the origin of systematic intellectual thinking about market capitalism began with Adam Smith's The Wealth of Nations. Much of the analytical efforts of economists from mid-19th to mid-20th centuries were devoted to proving Adam Smith's basic proposition that "a decentralized economy motivated by self-interest" would allocate resources more efficiently than other alternatives (Arrow and Hahn, 1971, pp. vi-vii). This conception envisioned the economy as a market system guided by the "invisible hand" toward smooth functioning, coordinating "autonomous individual choices in an interdependent world" (Evensky, 1993).

The process of developing a concrete and analytic vision of a capitalist market economy overlooked the fact that Smith's own vision of the economy, the subject of his book The Wealth of Nations, was embedded in his vision of a moral-ethical system. And that system was described well in Smith's book, The Theory of Moral Sentiments, written more than one and half decade earlier than The Wealth of Nations. Arguably, the first book established the institutional framework, or the rules of behavior for participants in the economy envisioned in The Wealth of Nations (Sen, 1982, 1987; Evensky, 1993, 2011; Mirakhor and Hamid, 2009; Askari et al., 2012).

Whereas conventional economics considered Smith's notion of "invisible hand" as a coordinator of independent decisions of market participants, in both The Theory of Moral Sentiments and in The Wealth of Nations, the metaphor refers to the design by the Supreme Creator, "who arranged the connecting principles such that the actions of all those seeking their own advantage could produce the most efficient allocation of resources, and thus the greatest possible wealth for the nation. This is indeed a benevolent designer" (Evensky, 1993, p. 9). Smith contended that the objective of the Divine Design must have been the happiness of humans "when he brought them into existence. No other end seems worthy of that supreme wisdom and divine benignity which we necessarily ascribe to him..." (Smith, 1976, pp. 186-189). Smith's major contribution in The Theory of Moral Sentiments is to envision a coherent moral-ethical social system consistent with the Supreme Creator's design and how each member of society would enforce ethical positions.

Recognition of human frailties led Smith to realize the need for an organic co-evolution of individual and society in a stage-wise process of accumulation of ethical system of values and its transfer from one generation to next. While it is possible for any given society to move forward or stagnate and even regress, the benevolence of the invisible hand of the "Author of nature" guides the totality of humanity in its movement toward the ideal human society. Compliance with and commitment to a set of values - virtues of prudence, concern for other people, justice, and benevolence — would ensure social order and cohesion.

\subsection{Smith and Arrow}

At the beginning of the second half of the 20th century, Kenneth Arrow, who was to win a Nobel Prize, and two of his co-authors Gerard Debreu and Frank Hahn, produced an elegant model that mathematically modeled Smith's conception of an economy. As this effort was primarily analytic, it abstracted from much of the well-spring of Smith's thought on the institutional scaffolding of the economy. Nevertheless, a crucial dimension of Smith's insight was not only preserved but also analytically demonstrated. In Smith's conception, the working of an economy relying on the market within the moral-ethical framework envisioned in The Theory of Moral Sentiments, where members of the society shared the risks of the economy. His insight into specialization and division of labor showed how efficiency and gains from trade are possible if the risks of economic activity are shared. 
The work of Arrow and his colleagues $(1954,1971)$ led to the important result that in a decentralized market economy, the best allocation allows risk to be shared by the members of the society according to the ability of each participant to bear her/his share of risk. Two key assumptions of this work were complete contracts and complete markets. The first meant that it was possible to design transaction contracts that cover all contingencies. The second meant that there was a market available in which every conceivable risk could be traded or insured.

Crucially, in this optimal risk allocation (sharing) model, all future payoffs to transaction were contingent on the outcome of the project subject of the transactions. That is, there was no ex-ante determined rate of return; all returns were contingent on the outcome of the activity being financed. While not stated explicitly in his analytical work, Arrow subsequently made clear that it is "possible that the process of exchange requires or least is greatly facilitated by the presence of several...virtues (not only truth, but also trust, loyalty and justice) in future dealings... The virtue of truthfulness in fact contributes in a very significant way to the efficiency of the economic system... ethical behavior can be regarded as socially desirable institution which facilitates the achievement of economic efficiency in a broad sense" (Arrow, 1971, pp. 345-346). For example, if the institution of trust is strong in an economy, the universe of complete contracts can be replicated by simple contracts entered into by parties stipulating that terms and conditions of the contracts would be revised as contingencies arise. Arrow himself was to place emphasis on trust as the lubricant of the economy (Arrow, 1974).

Despite Arrow's attention to some important elements of the institutional structure that were integral to Smith's vision of an economy, the economics profession developed its own vision of that economy, focusing primarily on two concepts of "invisible hand" and "self-interest". The first was mentioned only once in The Wealth of Nations (see Smith, 1976: 456) and the manner in which the second was used by economists has been referred to by Walsh (2000) as a "vulgar...misunderstanding" of what Smith meant by "self-interest". This "narrowing" of Smith's view was subject of rather sharp criticism by Amartya Sen $(1982,1987)$ who suggested that: "Indeed, it is precisely the narrowing of the broad Smithian view of human beings in modern economics that can be seen as one of the major deficiencies of contemporary economic theory. This impoverishment is closely related to the distancing of economics from ethics" (Sen, 1987).

\subsection{Smith and Ethical Rules}

A careful reading of Moral Sentiments and The Wealth of Nations provides support for Sen's position. Even beyond Sen's spirited criticism of the misunderstanding of economists on Smith's (2006, pp. 186-189) self-interest motive is the latter's insistence on the need to comply with "general rules of conduct":

“...[that] are the commands and laws of the Deity, who will finally reward the obedient, and punish the transgressor of their duty... When the general rules which determine the merit and demerit of actions comes thus to be regarded as the laws of an all-powerful being, who watches over our conduct, and who, in a life to come, will reward the observance and punish the breach of them - they necessarily acquire a new sacredness from this consideration. That our regard to the will of Deity ought to be the supreme rule of our conduct can be doubted of by nobody who believes his existence. The very thought of disobedience appears to involve in it the most shocking impropriety. How vain, how absurd would it be for man, either to oppose or to neglect the commands that were laid upon him by infinite wisdom and infinite power. How unnatural, how impiously ungrateful not to reverence the precepts that were prescribed to him by the infinite goodness of his Creator, even though no punishment was to follow their violation! The sense of propriety, too, is here well supported by the strongest motive of self-interest. The idea that, however, we may escape the observation of man, or be placed above the reach of human punishment, yet we are always acting under the eye and exposed to the punishment of God, the greatest avenger of injustice, is a motive capable of restraining the most headstrong passions, with those at least who, by constant reflection, have rendered it familiar to them." 
Consideration of the above extract as well as the rest of The Theory of Moral Sentiments leads to at least three observations. First, this is the Smith that has been ignored by the economics profession. The Smith of economics is the author of the self-interest motive that is the basis of utility and profit maximization at any cost to the society, including the impoverishment and exploitation of fellow human beings as well as the destruction of the environment. Second, Smith makes clear in The Theory of Moral Sentiments that compliance with the rules prescribed by the Creator and with the rules of the market was essential to his vision. Third, it is also clear that Smith considers the internalization of rules - being consciously aware of the ever-presence of the Creator and acting accordingly - as crucial to all human conduct, including economics. A careful reading of Moral Sentiments shows that Smith shares some of the fundamental institutional scaffolding of Islam; belief in the One and Only Creator; belief in accountability of the Day of Judgement; belief in the necessity of compliance with the rules prescribed by the Creator; and belief that justice is achieved through full compliance with these rules. ${ }^{4}$

\subsection{An Arrow-Debreu Economy}

An economy in which there are contingent markets for all commodities - meaning that there are buyers and sellers who promise to buy or sell given commodities "if and only if" a specified state of the world occurs — is called an Arrow-Debreu economy. In such an economy, it is the budget constraints of the participants that determines the quantity bought of each contingent commodity at the price prevailing in the market. Since these commodities are contingent on future states, they are risky. Therefore, the budget constraints of individuals determine the risk-bearing ability of each market participant. Arrow (1971) recognized that requiring such a market is unrealistic, stating: "Clearly, the contingent commodities called for do not exist to extent required, but the variety of securities available on the modern markets serve as a partial substitute". Such securities, referred to as Arrow Securities, whose payoffs could be used to purchase commodities, would reduce the number of markets required while replicating the efficiency of risk allocation of complete contingent markets. Associated with complete markets are complete contracts. These are agreements contingent on all states of nature. In the real world, not all contracts can cover all future contingencies. Therefore, they are said to be incomplete contracts and may indicate inefficiencies in exchange. However, as suggested earlier, optimal contracts can be devised, provided there is mutual trust between the parties to the contract. That would be a simple contract with provisions for modification of terms and conditions should contingencies necessitate change.

A compelling case can be made that, in so far as the financial instruments are Arrow Securities, i.e., their payoff is contingent on the "state of nature" and depend on the outcome and not on fixed, predetermined interest rates and represent risk-sharing, this ideal system would have many characteristics of an ideal Islamic system (Mirakhor and Askari, 2017). However, not all Arrow Securities would satisfy Shari'ah requirements, as some may well represent contingent debt contracts to deliver a fixed predetermined amount of money if a given state of world occurs. These may not, therefore, represent ownership claim either. Shares of common stock of open corporations do meet these requirements. They are residual ownership claims and receive returns contingent on future outcomes; they are "proportionate claims on the pay offs of all future states" (Fama and Jensen, 1983). These payoffs are contingent on future outcomes. Stock markets that are well-organized, regulated, and supervised are efficient from an economic point of view because they allocate risks according to the risk-bearing ability of the participants. In essence, this is the contribution of the Arrow-Debreu model of competitive equilibrium (1954; see also Arrow, 1971), according to which efficient risk-sharing requires that the risks of the economy are allocated to market participants in accordance with their "respective degree of risk tolerance" (Hellwig, 1988). 


\subsection{What Happened to Smith-Arrow Risk-Sharing Ideal?}

The economic/financial system envisioned by Smith and analytically modeled by Arrow and his colleagues did not materialize. By all counts, this was not because it was altogether unrealistic and not implementable, but because the whole project was derailed. Instead of optimally sharing the risk of the economy, the financial system ended up shifting it. The process began in the 1980s and culminated in the crisis of 2007/2008. As mentioned earlier, what the Arrow-Hahn and the Arrow-Debreu models set out to do was to analytically conduct a rigorous demonstration of the proposition that a decentralized economy motivated by self-interest would be compatible with a coherent disposition of economic resources that could be regarded, in a well-defined sense, as superior to a large class of possible alternative disposition ..." (Arrow and Hahn, 1971, pp. vi-vii). However, as Evensky (1989, p. 12) suggests, "the Smithian story told by Arrow and Hahn — and they are representative of modern economists — is an abridged edition. The spring that motivates action in Smith's story has been carried forward, but much of the rest of his tale has been forgotten".

It can be argued, as Arrow (1971) himself seems to imply, that the "rest of" Smith's "tale" would have been his vision of the institutional infrastructure (rules of behavior) that is envisioned in the Theory of Moral Sentiments, and, as such, it is unlikely that abstracting from them would be change the outcome of the mathematical analysis of Arrow-Debreu and/or Arrow-Hahn. Furthermore, had actual finance developed along the trajectory discernible from these works, i.e., steps taken toward completion of markets and of contracts, keeping in mind the overall institutional framework for the economy as envisioned by Adam Smith, the result might have been the emergence of conventional finance different from the contemporary system. That system would instead be dominated by contingent, equity, and risk-sharing financial instruments.

\subsection{Can Economics Explain a Positive Predetermined Rate of Interest?}

Perhaps the most influential factor in derailing that trajectory is the existence and the staying power of a fixed, predetermined rate of interest for which there has never been a rigorous theoretical explanation. All, so-called theories of interest from the classical economists to contemporary finance theories explain interest rate as the price that brings demand for and supply of finance into equilibrium. This clearly implies that interest rates emerge only after demand and supply forces have interacted in the market and are not ex-ante prices. In fact, in some theoretical models, there is no room for a fixed, ex-ante predetermined rate of interest. For example, introducing such a price into the Walrus or Arrow-Debreu-Hahn models of general equilibrium (GE) leads to the collapse of the models as they become overdetermined. As Cowen (1983, pp. 609-611) suggested:

\footnotetext{
"Since the prices of all goods, whether present or future, are already specified by our set of Arrow-Hahn-Debreu equations, to now impose a discount rate on the economy (however derived) would overdetermine our system of equations. Hence, the interest rate is not the prices of capital goods or durable consumption goods. Instead, the own rates of return are given by the intertemporal price ratios we examine. Not only can there be no explanation of own interest rates that is not dependent upon our explanation of relative prices, but there can be no explanation of own interest rates which is not identical to our description of intertemporal relative price. However, if the goods are located in different time periods, then they must be considered different goods... The logical status of a theory of interest across different goods is rather dubious - how is it any different from a theory of "interest" which compares the price of apples to price of oranges? ... Once we define the interest rate as the set of intertemporal price ratio percentages, GE (general equilibrium) theory losses its ability to tell us anything specific about the magnitude of interest rates. These rates may be positive, negative, or even zero. Most likely, our system of equations will simultaneously contain all three possibilities as solutions."
}

Even though no satisfactory theory of a positive, ex-ante fixed rate of interest exists, all financial theory developed in the post-Arrow-Debreu-Hahn period assumed its existence in the form of a risk-free asset, 
usually Treasury Bills, as a benchmark against which the rates of return of all other assets, importantly equity returns, were measured. These include theories such as the Capital Asset Pricing Model (CAPM), Modern Portfolio Theory (MPT), and the Black-Scholes option pricing formula for valuing options contracts and assessing risk. For all practical purposes, the assumption of a risk-free interest rate introduced an artificial floor into the pricing structure of the real sector of the economy, and into all financial decisions. It can be argued that it is the existence of this exogenously imposed rate on the economy that transformed Arrow-Debreu vision of a risk-sharing economy and finance. The resulting system became one focused on transferring or shifting risk rather than sharing it. Such a system needed strong regulation to limit the extent of both.

Further developments in finance theory provided analytical rationale for strengthening interest rate-based debt financing as well as emergence of aggressive deregulation of finance in all economies. One was the ModiglianiMiller Theorem of neutrality of capital structure of firms. In essence, this theorem asserted that the value of a firm is independent of its capital structure. This implied that since firms want to maximize their value and since Modigliani-Miller showed that the value of the firm is indifferent as to its capital structure, firms would prefer to incur higher debt levels rather than issue additional equity, since the latter means erosion of ownership and, moreover, there is considerable incentive to opt for debt because of its tax advantages. However, the risk of additional debt would be shifted to other stakeholders (Jensen and Meckling, 1976).

Another development was the Efficient Market Hypothesis (EMH), which claimed that in an economy similar to that of Arrow-Debreu, prices prevailing in the market contained all relevant information such that there would be no opportunity for arbitrage. The implication was that if market efficiency is desirable, then the markets should be allowed to move toward completion, through innovation and financial engineering, in order to create financial instruments to allow insurance against all risks. For this to happen, it had to be demonstrated that it is possible to develop such a wide array of instruments and that regulation had to become passive or even regressive to allow an incentive structure to induce innovation. The latter was initiated in almost all industrial countries in the 1980s and continued with an accelerated pace until the 2007/2008 crisis. The former had already been demonstrated by the theory of spanning, showing that one basic financial instrument can be spanned potentially into an infinite number of instruments (see Askari et al., 2010b, 2012). These developments, coupled with the high magnitude of leverage available from money-credit-debt-leverage creation process characteristic of a fractional reserve banking system represented an explosive mix that reduced the vision of Adam Smith to the rubble of post-2007/2008 crisis. The Arrow-Debreu vision of an economy in which risk was shared was first transformed into an economy in which the focus became risk transfer, but which quickly transformed into one in which risks were shifted, ultimately, to taxpayers (Mirakhor and Krichene, 2009; Sheng, 2009).

A question that arises is whether the risk-transferring, risk-shifting system is highly unstable and creates boombust bubble cycles and what explains its staying power. There are a number of reasons (see Askari et al., 2012), but an important argument is that it is relatively inexpensive to borrow than either postpone consumption, in case of consumers, or issue equity shares, in case of business. However, the financial costs (aside from its human costs) to the society of establishing and administering a debt economy are, for the most part, hidden. ${ }^{5}$ To explain the latter point, consider the findings of the contract theory. ${ }^{6}$ The argument goes that, given the axioms of scarcity, selfinterest, and rationality, there is a set of contracts referred to as "impossible contracts" because either both or at least one side have no incentive to enter into some contracts. To make "impossible contracts" possible, contracts have to be designed to become "incentive-compatible", meaning that the contract would have to include features that would incentivize parties to an impossible contract to agree to participate.

One such "impossible contract" is a debt contract. It is impossible because, again given the axioms of conventional economics, the borrower has no incentive to repay a loan. A debt-based economy therefore has to create a positive/negative incentive structure to make debt contracts possible. On the positive side, tax, policy, administrative, and legal incentives are created for parties to engage in debt contracts. On the negative side, an edifice of legal, administrative, and retributive institutions is established to enforce debt contracts. Seldom, if ever, 
are the costs to the society of establishing and then running this incentive structure necessary to make debt contracts possible mentioned. The only item in this incentive structure that is recognized is the tax incentive. However, even here, the opportunity costs of tax write-offs attributable to debt contracts to the society of forgone revenue to the governments that could otherwise be allocated to social investment programs are seldom acknowledged or mentioned. ${ }^{7}$

\subsection{Islamic Finance: The Foundations}

The fountainhead of all Islamic thought is the Qur'an. All knowledge Islamic, including that of finance, must find its roots in the Qur'an. The starting point of this discussion here is therefore Verse 275 of Chapter 2 of the Qur'an, particularly the part of the Verse that declares contract of Al-Bay' permissible and that of Al-Riba non-permissible. Arguably, these few words can be considered as constituting the organizing principle - the fundamental theorem as it were - of an Islamic economy. English translations of the Qur' an render Al-Bay' as "commerce" or "trade". They also translate Al-Tijarah as "commerce" or "trade". Consulting major lexicons of Arabic language (such as Lisan Al-Arab, Mufradat Alfaz Al-Qur'an, Lane's Arabic Lexicon, Al-Tahquiq fi Kalamat Al-Qur'an Karim, among others) reveals that there is a substantive difference between Al-Bay' and Al-Tijarah. Relying on various verses of the Qur'an (e.g., Verse 254: Chapter 2; 111: 2; 29-30: 35; 10-13: 61), these sources suggest that trade contracts (Al-Tijarah) are entered into in the expectation of profit (ribh). On the other hand, Al-Bay' contracts are defined as Mubadilah Al-Maal Bi Al-Maal - exchange of property with property. In contemporary economics, this phrase would be understood as the exchange of property rights claims. These sources also suggest a further difference in that those who enter into a contract of Al-Bay' (exchange) expect gains but are cognizant of probability of losses (khisarah). ${ }^{8}$

Given the above, a few points should be noted. First, all transactions, except spot exchange, involve time. From an economic point of view, time transactions involve a commitment to do something today in exchange for a promise of a commitment to do something in the future. All transactions involving time are subject to uncertainty, and uncertainty involves risk. Risk exists whenever there is more than one outcome possible. Consider, for example, a contract in which a seller commits to deliver a product in the future against payments today. There are a number of risks involved. There is a price risk for both side of the exchange; the price may be higher or lower in the future. In this case, the two sides are at risk which they share once they enter into the contract agreement. If the price in the future is higher, the buyer would be better off, and the price risk has been shed to the seller. The converse is true if the price is lower. Under uncertainty, the buyer and seller have, through the contract, shared the price risk. There are other risks that the buyer takes, including the risks of non-delivery and quality risk. The seller, on the other hand, also faces additional risks, including the risk that the price of raw materials, transportation, and delivery costs may be higher in the future. This risk may also be lower. Again, these risks have been shared through the contract. The same argument applies to deferred payment contracts.

Second, it may appear that spot exchange or cash sale involves no risk. However, price changes post-completion of spot exchange do occur often. The two sides of a spot exchange share this risk. Moreover, from the time of the classical economists, it is known that specialization through comparative advantage provides the basis for gains from trade. However, in specializing, a producer takes a risk of becoming dependent on other producers specialized in production of what he needs. Again, through exchange, the two sides to a transaction share the risk of specialization. Additionally, there are pre-exchange risks of production and transportation that are shared through the exchange. Therefore, it can be inferred that by mandating exchange (Al-Bay'), the Qur'an has ordained risksharing in all exchange activities.

Third, it appears that the reason for the prohibition of the contract of Al-Riba is that opportunities for risksharing are non-existent in this contract. It may be argued that the creditor does take risk - the risk of default. However, it is not risk taking per se that makes a transaction permissible. A gambler takes risks as well, but gambling is haram. Instead, what seems to matter is opportunity for risk-sharing. Al-Riba is a contract of risk 
transfer, at best, or of risk-shifting, at worst. As Keynes $(1932,1936)$ emphasized in his writings, if interest rates did not exist, the financier would have to share all the risks that the entrepreneur faces in producing, marketing, and selling a product (see Mirakhor and Krichene, 2009). However, by decoupling his future gains from the outcome of a project, by loaning money today for more money in the future, the financier transfers all risks to the entrepreneur. Fourth, it is clear that by declaring the contract of Al-Riba non-permissible, the Qur'an intends for humans to shift their focus to risk-sharing contracts of exchange.

It can be inferred from the above discussion that there are two types of contracts involving time:

(i) Contracts over time (or on spot) involving trade in which there is expectation of gain (ribh); and

(ii) Contracts over time involving an exchange in which there is expectation of gain (ribh) or loss (khisarah).

Here, a question arises. The Qur' an identifies three types of transactions: interest rate-based debt transactions (Al-Riba), trade transactions (Al-Tijarah), and exchange (Al-Bay). Verse 275 of Chapter 2 of the Qur' an defines the first type of transaction, while Verse 282 of Chapter 2 defines trade comprehensively. The question is about investment since it does not fall into the two categories of transactions. There are two possible answers. First, that it is ignored in the Qur'an; an answer no Muslim would accept since we believe nothing is ignored in the Qur'an. The second answer would be that the third type of transaction mentioned in Verse 275 of Chapter 2, Al-Bay' must refer also to contracts of investment with uncertain outcomes in terms of gain or loss. This, of course, does not mean that mudarabah and musharakah could not be used for longer-term trade in expectations of profits to be shared and for long-term investment, as was the case for centuries in the Muslim world as well as in Europe in the Middle Ages.

Borrowed from Muslims, and known as "commenda" in Western Europe, ${ }^{9}$ mudarabah became quite popular as a means of financing long-term trade and investment (Mirakhor, 1983; Brouwer, 2005; Fischel, 1933; Udovitch, 1967, 1969, 1970; Goitein, 1955, 1964). Lopez (1976) suggests that there is a consensus among medieval historians that the commenda was of the highest importance and greatly contributed to the rapid growth of trade and investment, which led to economic change and growth in Europe. Commenda's contributions to the industrial development of the Ruhr Valley in Germany and in building railroads in Europe were particularly pronounced (see Mirakhor, 1983; Putri, 2017). Therefore, what needs emphasis is that Al-Bay' covers long-term investment contracts that allow the growth of employment and income and expansion of the economy (Bakkali, 2017). The focus of Al-Tijarah and all its financing instruments is the trade of commodities already produced. In effect, Islam meets the financing needs of trade as well as the requirements of resource allocation, investment, production, employment, income creation, and risk management.

\subsection{Islamic Rules Governing Exchange}

Given the above, major economic implications follow. First, as the definition of Al-Bay' indicates, it is a contract of exchange of property. This means that the parties to exchange must have property rights over the subjects of contract antecedent to the exchange. Second, parties must have the freedom not only to produce what they wish but also with whom they wish to exchange. Third, parties must have freedom to contract. Fourth, there must be means of enforcing contracts. Fifth, exchange requires a place for the parties to complete their transactions, meaning a market. Sixth, markets need rules of behavior to ensure an orderly and efficient operation. Seventh, the contract of exchange requires trust among the parties as to commitments to perform according to the terms and conditions of exchange. Eighth, there must be rules governing the distribution of proceeds. Lastly, there must be redistributive rules and mechanisms to correct for pattern of distribution emerging out of market performance. These are rules that govern the redemption of the rights of those who are not parties to the contract directly but who have acquired rights in the proceeds because, one way or another, they or their properties have contributed to the production of what is the subject of exchange. These implications are discussed below (see Askari et al., 2012). Figure 1.2 outlines the ambit of Islamic rules governing exchange. 


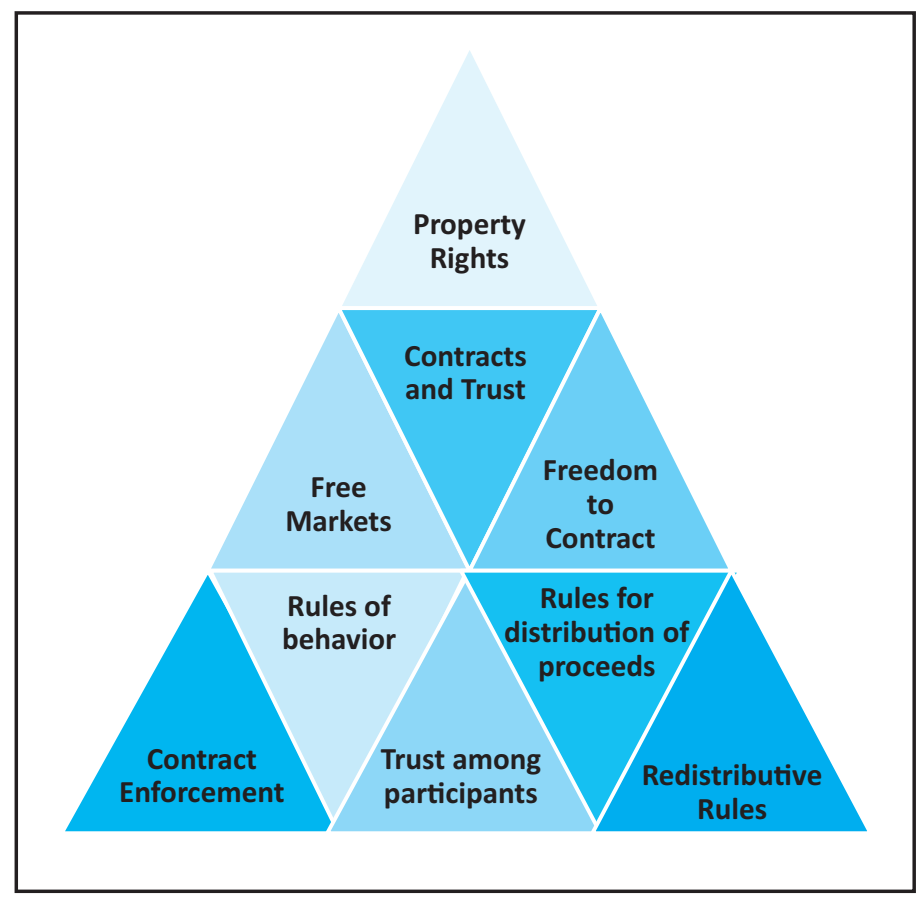

Figure 1.2. Islamic Rules Governing Exchange.

\subsubsection{Property Rights}

Briefly, the principles of property rights in Islam include the following:

(i) Allah (swt) has created all property and He is the ultimate owner;

(ii) Resources created by Allah (swt) are at the disposal of all humans to empower them to perform duties as prescribed by the Creator;

(iii) While the ultimate ownership is preserved for the Creator, humans are allowed to combine their physical and intellectual abilities with the created resources to produce means of sustenance for themselves and others;

(iv) The right of access to resources belongs to all of mankind universally;

(v) Humans can claim property rights over what is produced through their own labor or transfers through gift giving, exchange, contracts, inheritance, or redemption of rights in the produced property;

(vi) Since created resources belong to all humans, the inability of a person (physical, mental, or circumstances) to access these resources does not negate the individual's right to these resources;

(vii) These rights have to be redeemed - this establishes the rule of sharing with the less able;

(viii) Sharing is implemented through redistributive mechanisms, such as zakah, which refer to the redemption of rights and not charity;

(ix) Since work and transfers are the only sources of property rights claims, all sources of instantaneous property rights creation, such as theft, bribery, gambling, and riba are prohibited;

(x) Unlike the conventional system of property rights, Islam imposes strict limits on the freedom of disposing of property; there is no absolute freedom for the owner to dispose of property as there are rules against extravagance, waste, destruction of property, or its use in prohibited transactions;

(xi) Property rights must not lead to accumulation of wealth as the latter is considered the life blood of the society which must constantly circulate to create investment, employment, income, and economic growth opportunities; and 
(xii) Once the principles governing property rights are observed, particularly the rule of sharing, the owner's right to the remaining property, cleansed of others' rights, is inviolate. For more detailed discussions, see Mirakhor, 2009; Mirakhor and Askari, 2017.

It is through its rules of property rights that Islam envisions economic growth and poverty alleviation in human societies (Al-Labban, 1967; Habachi, 1962; Khadduri, 1977). The latter is accomplished through the discharge of the obligation of sharing derived from the property rights principles which envision the economically less able as the silent partners of the more able. In effect, the more able are trustee-agents in using resources created by Allah (swt) on behalf of themselves and the less able.

In contrast to property rights principles of the conventional system, here, property rights are not means of exclusion but of inclusion of the less able in the income and wealth of the more able as a matter of rights that must be redeemed. In the conventional system, rich help the poor as a demonstration of sympathy, beneficence, benevolence, and charity. In Islam, the more able are required to share the consequences of the materialization of idiosyncratic risks — illness, bankruptcy, disability, accidents, and socioeconomic disadvantaged — for those who are unable to provide for themselves. Those who are more able diversify away a good portion of their own idiosyncratic risks using the risk sharing instruments of Islamic finance. The economically well-off are commanded to share risks of those who are economically unable to use the instruments of Islamic finance. It can be argued that unemployment, misery, poverty, and destitution in any society are prima facie evidence of violation of property right rules of Islam and/or non-implementation of Islamic instruments of risk-sharing. In Islamic teachings, the risks that would face the future generations are shared by the present generation through the rules of inheritance. These rules break up the accumulated wealth as it passes from one generation to another, to enable sharing risks of a larger number of people.

\subsubsection{Contracts and Trust}

Basically, a contract is an enforceable agreement. Its essence is commitment. Islam anchors all socio-politicaleconomic relations on contracts. The fabric of the Shari'ah itself is contractual in its conceptualization, content, and application. Its very foundation is the primordial covenant between the Creator and humans (see Verses 172-173: Chapter 7). In an unambiguous verse (152: 6), the Qur'an urges the believers to fulfill the covenant of Allah (swt). This is extended to the terms and conditions of all contracts through another clear passage (Verse 1, Chapter 5) in which believers are ordered to be faithful to their contracts. They are ordered to protect faithfulness to their covenants and what has been placed in trust with them as a shepherd protects sheep (Verse 8: Chapter 32; also 34: 17; 172: 2; 91-92: 16). Thus, believers do not treat obligations of contracts lightly; they will take on contractual obligations only if they intend fully to fulfill them. Hence, their commitments are credible.

Contracts are means of coming to terms with future risks and uncertainty. They allocate risks by providing for future contingencies, and set obligations for each party and each state in the future as well as remedies for breach of contracts. Generally, there are four motives for entering into a contract: sharing of risk, transfer of risk, alignment of incentives, or to minimize transaction costs. Partnership contracts and the purchase of equity shares are examples of risk-sharing. Entering into an insurance contract is an example of transferring risks for a fee to those who can better bear them. Risk-shifting occurs when the risks of a transaction or a contract between two parties are shifted to a third party not directly involved in the transaction. This concept was discussed by Jensen and Meckling (1976) in the context of corporate managers resorting to debt finance instead of issuing additional equity, thus shifting the risk of debt burden to other stakeholders. To align incentives, one party (usually the principal) enters into a contract with another (an agent) through which incentives are created for the latter to take actions that serve their jointsurplus maximization objective (Hart and Holmstrom, 1987). Contracts that are designed to reduce transaction 
costs are usually aimed at establishing a stable, long-term relationship between parties in order to avoid ex-ante information, search and sorting costs, as well as ex post bargaining costs.

There is an organic relationship between contract and trust. Without the latter, contracts become difficult to negotiate and conclude, and costly to monitor and enforce. When and where trust is weak, complicated, and costly, administrative devices are needed to enforce contracts. Problems are exacerbated when, in addition to lack of trust, property rights are poorly defined and protected (Sheng, 2009). Under these circumstances, it becomes difficult to specify clearly the terms of contract, since transaction costs - that is, search and information costs, bargaining and decision costs, and contract negotiations and enforcement costs — are high. Consequently, there is less trade, fewer market participants, less long-term investment, lower productivity, and slower economic growth. Weakness of trust creates the problem of lack of credible commitment which arises when parties to an exchange cannot commit themselves or do not trust that others can commit themselves to performing contractual obligations. Empirical research has shown that where the problem of a lack of commitment exists and is significant, it leads to disruptions in economic, political and social interaction among people. Long-term contracting will not be possible, and parties to exchange opt for spot market or very short-term transactions (see, e.g., Halaissos and Bertaut, 1995; Knack and Keefer, 1997; Zak and Knack, 2001; $\mathrm{Ng}$, 2015; Guiso et al., 2004 and 2005).

Considering these issues, one can appreciate the strong emphasis the Qur' an has placed on trust, trustworthiness (see Verse 27: Chapter 8; 57: 4), and the need to fulfill terms and conditions of contracts, covenants, and promises one makes. These rules solve the problem of credible commitment and trust, thus facilitating long-term contracts. To illustrate the importance of trust, consider the role of complete contracts in the neoclassical theory of competitive equilibrium (Arrow, 1971). A complete contract fully specifies all future contingencies relevant to the exchange. In the real world, a vast majority of contracts are incomplete. This requirement, therefore, is considered too stringent and unrealistic. Not only does ignorance about all future contingencies make writing complete contracts impossible, even if all future contingencies are known, it would be nearly impossible to write a contract that can accommodate them all. However, if the parties to a contract trust each other, they can agree to enter into a simple contracts and commit to revising its terms and conditions as contingencies arise.

\subsubsection{Markets}

A major reason for a contract of exchange is that the parties to the contract wish to improve upon their own precontract welfare. For this to happen, parties must have the freedom to contract. This, in turn, implies freedom to produce, which calls for clear and well-protected property rights to permit production and sale. To freely and conveniently exchange, the parties need a place to do so, i.e., a market. To operate efficiently, markets need rules of behavior and clear, unambiguous rule-enforcement mechanisms to reduce uncertainty in transactions. Markets also need free flow of information. To reinforce the efficiency of market operations, trust has to be established among participants, transaction costs minimized, and rules established to internalize externalities of two-party transactions. Sheng $(2009$, p. 9) suggests that, "Successful markets all share three key attributes: the protection of property rights, the lowering of transaction costs and the high transparency".

To achieve these attributes, preconditions and infrastructures are needed, including:

(i) Freedom of market participants to enter and exit the market, to set their own objectives within the prescribed rules, to employ ways and means of their own choosing to achieve their goals, and to choose whomever they wish as their exchange partner;

(ii) An infrastructure for participants to access, organize, and use information;

(iii) Institutions that permit coordination of market activities;

(iv) Institutions to regulate and supervise the behavior of market participants; and

(v) Legal and administrative institution to enforce contracts at reasonable costs. ${ }^{10}$ 
Figure 1.3 summarizes the critical factors needed for the efficient functioning of markets.

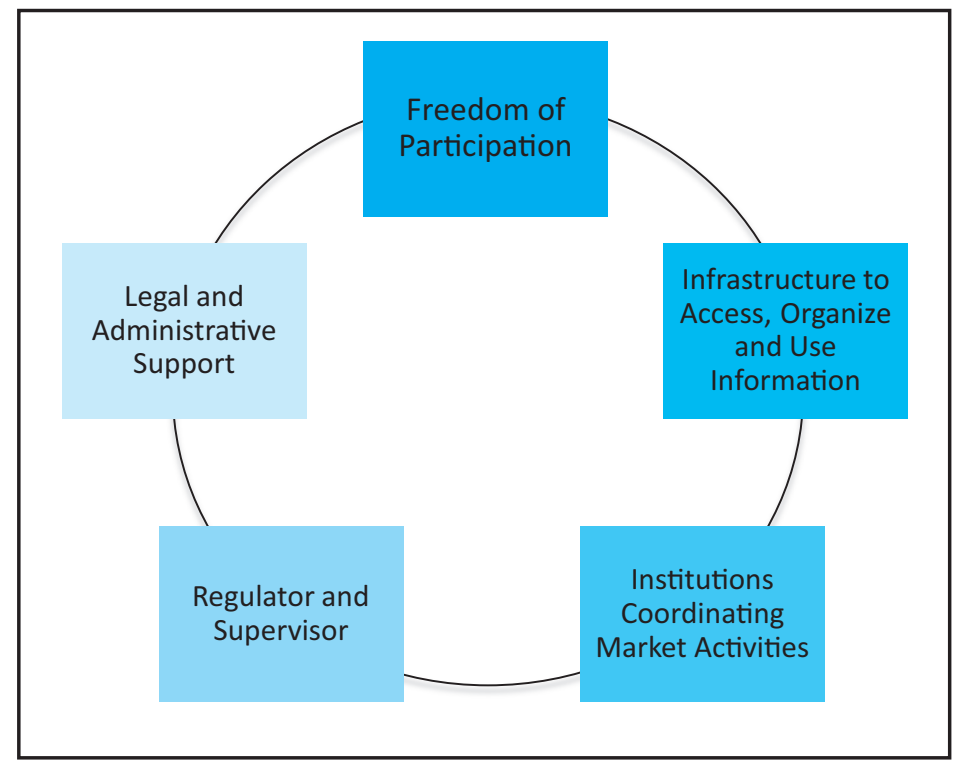

Figure 1.3. Critical Factors for Efficient Markets.

\subsubsection{Markets of the Prophet}

Both the Qur' an and the Sunnah place considerable emphasis on the rules of behavior. Once instated in Medina as the spiritual and temporal authority, the Messenger (saw) exerted considerable energy in operationalizing and implementing the property rights rules, the institutions of the market, the rules of exchange and contracts, as well as rules governing production, consumption, distribution, and redistribution. He also implemented rules regarding the fiscal operations of the newly formed state as well as governance rules. Specifically, regarding markets, before the advent of Islam, trade had been the most important economic activity in the Arabian Peninsula. A number of dynamic and thriving markets had developed throughout the area.

Upon arrival in Medina, the Messenger of Allah organized a market for Muslims structured and governed by rules prescribed by the Qur' an, and implemented a number of policies to encourage the expansion of trade and strengthen the market. Unlike the already existing market in Medina, and elsewhere in Arabia, the Prophet prohibited imposition of taxes on individual merchants as well as on transactions. He also implemented policies to encourage trade among Muslims and non-Muslims by creating incentives for non-Muslim merchants in and out of Medina. For example, traveling non-Muslim merchants were considered guests of the Muslims and their merchandise were guaranteed by the Prophet against (non-market) losses. The market was the only authorized place of trade. Its construction and maintenance were made a duty of State. As long as space was available in the existing one, no other markets were constructed. The Prophet designated a protective area around the market. No other construction or facility was allowed in the protective area. While trade was permitted in the area surrounding the market in case of overcrowding, the location of each merchant was assigned on a firstcome, first-served basis, but only for the duration of the trading day (Mirakhor and Hamid, 2009; Sadr, 2016).

After the conquest of Mecca, rules governing the market and the behavior of participants were institutionalized and generalized to all markets in Arabia. These rules included, inter alia:

(i) No restriction on inter-regional or international trade, including no taxation on entering into or existing out of markets and on imports and exports;

(ii) Free movement of inputs and outputs between markets and regions; 
(iii) No barrier on entry to or exit from the market;

(iv) Information regarding prices, quantities, and qualities were to be known with full transparency;

(v) Every contract had to fully specify the property being exchanged, the rights and obligations of each party to the contract, and all other terms and conditions;

(vi) The state and its legal apparatus guaranteed contract enforcement;

(vii) Hoarding of commodities were prohibited as were price controls;

(viii) No seller or buyer was permitted to harm the interests of other market participants, e.g., no third party could interrupt negotiations between two parties in order to influence the outcome in favor of one or the other party;

(ix) Short changing, i.e., not giving full weights and measure, was prohibited; and

(x) Sellers and buyers were given the right of annulment depending on circumstances.

These rights protected consumers against the moral hazards of incomplete, faulty, or fraudulent information. Interference with supply before market entrance was prohibited as they would harm the interests of the original seller and the final buyer. These and other rules — such as trust and trustworthiness as well as faithfulness to the terms and conditions of contracts - substantially reduced transaction costs and protected market participants against risks of transactions (Mirakhor and Hamid, 2009; Sadr, 2016).

\subsection{Islamic Financial Market and Instruments}

A financial market organized according to the Islamic precept would be embedded in an economy in which the institutional scaffolding, i.e., rules of behavior described, would be operational. Such a market would be served by a full spectrum menu of financial instruments (Chapra 2007; Mirakhor and Zaidi, 2007; Iqbal and Mirakhor, 2011; Haneef and Mirakhor, 2014; Maghrebi et al., 2016). The essential function of that spectrum would be spreading and allocating risk among participants rather than concentrating it among the borrowing class. In general, that spectrum will include instruments of risk-sharing for: (i) transactions (mu'amalat); (ii) redistributive instruments by which economically more able segment of the population shares the risk of the less able; and (iii) instruments that serve the inheritance rules specified in the Qur'an through which the wealth of a person at the time of passing is distributed among the present and future generations of inheritors.

The second set of instruments is used to redeem the rights of the less able in the income and wealth of the more able. These would not be instruments of charity, altruism, or beneficence, but instruments of redemption of rights of others as repayment of obligation of share. Figure 1.4 shows the broad objectives for Islamic financial markets and instruments.

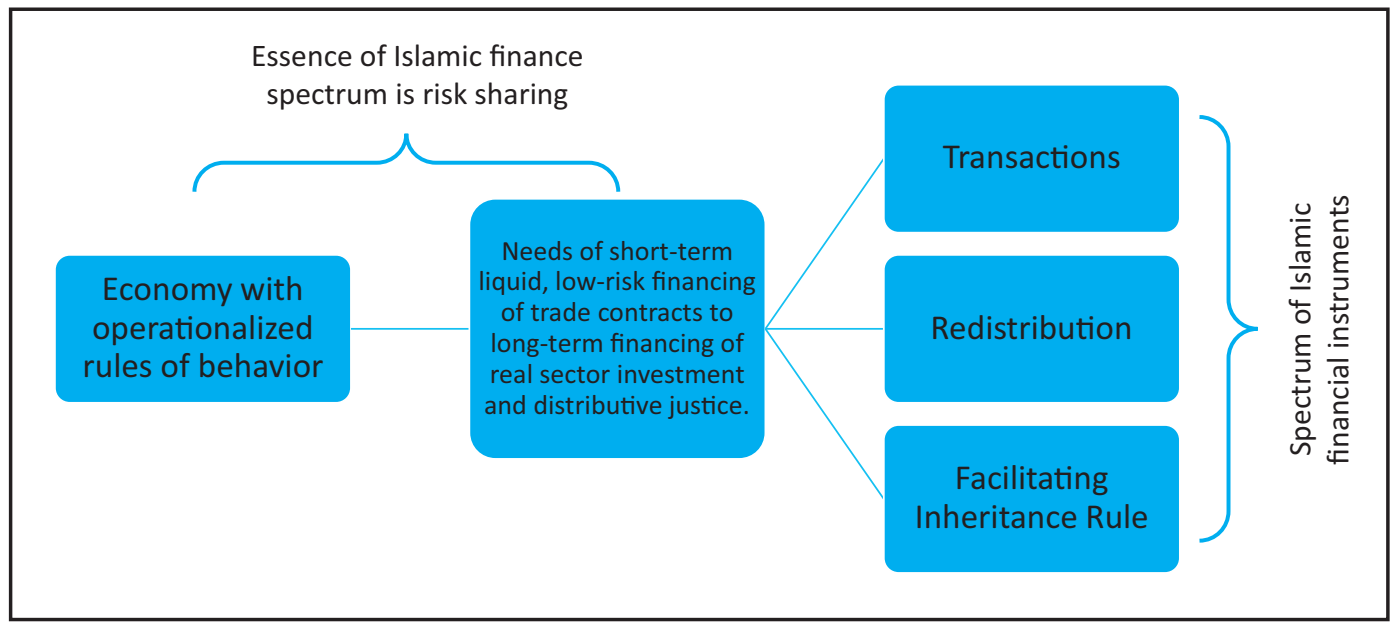

Figure 1.4. Islamic Financial Market and Instruments. 
The spectrum of ideal Islamic finance instruments would run the gamut between short-term liquid, lowrisk financing of trade contracts, to long-term financing of real sector investment. The essence of the spectrum is risk-sharing. At one end, the spectrum provides financing for purchase and sale of what has already been produced in order to allow further production. At the other end, it provides financing for what is intended or planned to be produced. In this spectrum, there does not seem to be room provided for making money out of pure finance where instruments are developed that use real sector activity only as virtual license to accommodate what amounts to pure financial transactions. There are duyun and qardh hassan that are non-interest-based debt, but only to facilitate real sector transactions in terms of consumption smoothing for those who have experienced liquidity shock. This is the case when a financier shares liquidity risk with the firms or consumers for whom the risk has materialized or for those who use non-interest borrowing as an insurance against liquidity shocks.

It may be argued that in a modern complex economy, there is need for a variety of ready-to-use means of liquidity, and so long as instruments being developed are, in the judgement of Shari'ah scholars, permissible, where is the harm? Usually, this argument starts with the reasoning that financial instruments that serve shortterm, trade-oriented transaction contracts, such as murabahah, are permissible. From there, the argument goes that any instrument with connection, no matter how tenuous to the real sector transactions, is also permissible. It is worth noting that transaction contracts permissible in Islam and the financial instruments intended to facilitate them are not the same thing. Islamic real sector transactions contracts ('uqud) that have reached us are all permissible. However, it is possible that a financial instrument designed to facilitate a given permissible contract may itself be judged non-permissible. As the proliferation of derivative instruments in the period of run-up to the 2007/2008 financial crisis demonstrated that the number of financial instruments that have some relation, even if only nominal, to a real sector transaction is limited only by the imagination of financial engineers. It is possible that a financial instrument may have weaker risk-sharing characteristics than the Islamic transaction contract it intends to serve.

\subsection{Islamic Finance Industry at the Present}

This book is about the reality on the ground as it is. Hence, it describes the workings of the Islamic financial system and, in particular, focuses on a comparative presentation of conventional and Islamic capital and money market as they exist today. The present configuration of the Islamic finance industry has a short history of a little over three decades of operation at levels that could be considered significant. Over this period, it has had a remarkable growth. Despite this performance, there are anxieties that the industry is on a trajectory that does not assure its convergence to its ideal path described above. This is because the energies of financiers and financial engineers serving the Islamic financial industry (IFI) are focused on the design and development of instruments that accommodate the low end of time and risk-return spectrum described above. The concern is that without effort at developing long-term investment instruments of risk-sharing, there is the possibility that the future development of the industry will continue to see more - albeit in greater variety of the same. That is, more short-term, liquid, and safe instruments with risk transfer or risk-shifting characteristics (Alaabed et al., 2016). In that case, IFI would have failed to achieve the hopes and aspirations embedded in the ideal vision of Islamic finance. That vision includes the emergence of a financial system with close links to the real sector of the economy, rather than a "paper economy" in which financial paper is traded without creating real sector added value. 


\section{Box 1.1. The Paper Economy}

"Paper economy" is a term used by the Nobel Laureate economist, James Tobin, who suggested in 1984 that "we are throwing more and more of our resources into financial activities remote from the production of goods and services, into activities that generate high private rewards disproportionate to their social productivity, a 'paper economy' facilitating speculation which is short-sighted and inefficient" (Tobin, 1984).

A paper economy has several distinctive characteristics:

(i) Its finance is speculative rather than productive. In the latter, one buys a share of a business after thought and deliberation on its risk-return characteristics and then holds on to it for the long run; one buys and owns. In the paper economy, one speculates on a piece of paper that represents debt or its derivative, or a stock or its derivative, and turns it over quickly without taking interest in the underlying activity that the paper represents. This is rentseeking instead of value-creating.

(ii) Its finance has a short-term focus: obsession with short-term results. This short-termism has no regard for the longterm implications or even short-term effects of the activity on third parties; "it involves buying pieces of paper and trading it back and forth in rapid turnover" (on short-termism, see Bogle, 2012, p. 47).

(iii) Its finance decouples from the real sector, gradually at first but then rapidly. A decade after James Tobin spoke the words quoted above, the brilliant President of Bundesbank, Hans Tietmeyer, was to warn that the financial sectors in advanced economies were decoupling from the real sector. The warnings were never heeded. The result was the 2007/2008 financial crisis.

(iv) Its finance is extractive of value from the real sector rather than adding value to the real economy.

(v) Its finance has no anchor in the real sector of the economy but crises that are triggered in the financial sector can be devastating to the real economy in terms of loss of jobs, and income (see also Power and Epstein, 2003; Epstein, 2005).

\section{How does the 'paper economy' look like today, some five years after the crisis?}

At the end of 2011, it was estimated that, in the US alone, the total nominal value of paper instruments (with no direct linkage to the real sector of the economy) "such interest rate swaps, collateralized debt obligations, derivatives such as commodity futures, stock indices, credit default swaps exceeded $\$ 700$ trillion". This compares to the "total value of capitalization of world's stocks and bond markets of $\$ 150$ trillion" at the same time. That is, the value of all the "paper" instruments in the US alone was five times larger than the total capitalization of all the stock and bond markets in the world (Bogle, 2012, p. 47).

To compare the relationship of the "paper" finance and real finance, consider that in the US over the past five years, "total equity IPO's (initial public offerings) provided fresh capital to young companies averaging $\$ 45$ billion annually. Secondary offerings provided additional equity capital averaging $\$ 205$ billion for a total of $\$ 250$ billion per year. Total volume of stock trading over the same period averaged $\$ 33$ trillion annually. Some 130 times the volume of equity capital". This implies that only $0.8 \%$ of finance went to equity and $99.2 \%$ to trading activity that does not add value to the real economy of the US. In other words, "speculation represented $99.2 \%$ of the activities" of the US market, and only $0.8 \%$ accounting for "capital formation" (see Bogle, 2012, pp. 1-10).

In fairness, it should be acknowledged that the IFI faces formidable challenges competing within the centuries old and well-entrenched system whose main fulcrum is the interest mechanism prohibited in Islamic finance. It should also be recalled that the non-availability of instruments in the conventional system to meet the demand of the Muslim investors for non-interest-based financial transactions represented a market failure. IFI, therefore, grew out of conventional finance to serve the here-to-fore unmet demand. In the process, it has had to compete with an industry in which interest reigns supreme. The first important challenge to and a constraint on the activities of IFI are the advantages and incentives granted for interest rate-based debt and credit contracts that are not granted risksharing and equity-based contracts. 
The second challenge stems from the fact that the conventional system centered on a fractional reserve banking system created opportunities for leverage that can be highly profitable. Proper Islamic finance modes of operation are limited as to their capacity to use or create highly leveraged positions due to constraints on interest rate-based debt creation. The third challenge for IFI is that there is a lack of credible, competitive, liquid, long-term, widely used Shari'ah-compliant instruments for liquidity management and hedging. Conventional finance has recourse to risk-free assets in the form of government treasury bonds.

Fourth, in Muslim countries, fiscal and monetary policies are interest rate-based. Hence, in addition to the lack of Shari'ah-compliant instruments issued by governments that IFIs can use for liquidity and hedging management, the governments' macroeconomic policies strengthen interest rate-based debt financing against which the IFI has to compete. In effect, the governments in Muslim countries define exogenously competitive conditions for IFI without leveling the playing field. Fifth, IFI cannot operate in isolation from the international financial markets. There are, however, conflicts between Shari'ah-compliant IFI contracts and the legal system of major financial systems (see Mirakhor and Haneef, 2014). These challenges must be overcome to allow IFI to continue its growth and embark on a trajectory of convergence with its ideal path. The last chapter of this book will propose ways and means of meeting these challenges.

\section{Questions and Problems}

1. Explain the relationships between the real and financial sectors of an economy and the functions performed by each.

2. Explain the differences between risk and uncertainty. Where do they originate? What is their function according to the Qur'an?

3. Explain the function of rules as they relate to risk and uncertainty.

4. Explain the difference between risk taking and risk sharing. Define risk transfer, risk sharing, and risk shifting. What types of risk do people face?

5. What is the most important characteristic that Adam Smith's vision of an economy shares with the Qur'anic vision? Elaborate.

6. Explain the difference between contemporary economics and Adam Smith's vision.

7. What is the major characteristic of an Arrow-Debreu economy? Explain.

8. Explain the differences between an Arrow-Debreu vision and that of contemporary economics.

9. Can contemporary economics explain the existence of a fixed, pre-determined interest rate? Explain.

10. Use the arguments of the chapter to explain why interest-based debt contracts are prohibited by the Qur'an.

11. Explain the Islamic rules governing the operations of an economy and its financial sector. Elaborate on these rules that operate in the capital market.

12. Explain some of the most important characteristics of Islamic finance as it is. 


\section{Bibliography}

Alaabed, A., M. Masih, and A. Mirakhor (2016). "Investigating Risk Shifting in Islamic Banks in the Dual Banking Systems of OIC Countries: Application of Two-step Dynamic GMM,” Risk Management, Vol. 18, No. 4, pp. 236-263.

Al-Isfahani, Al-Raqib (1992). Mufradat Alfaz Al Quran (Damascus: Dar Al-Qalam), p. 155.

Al-Labban, I. (1967). "Islam is the First Religious System to Recognize the Right of the Poor to the Wealth of the Rich," The Islamic Review, August, pp. 14-19.

Al-Mustafaoui, S. H. (1995). Al-Tahquiq Fi Kalamat Al-Quran Al-Karim (Tehran: Ministry of Islamic Culture and Guidance). Vol. 1, pp. 363-365.

Arrow, K. J. (1971). Essays in the Theory of Risk-Bearing (Chicago: Markham Publishing Company) pp. 121-133, 143; 239-266.

Arrow, K. J. and G. Debreu (1954). "The Existence of an Equilibrium for a Competitive Economy," Econometrica, Vol. XXII, pp. 265-290.

Arrow, K. J. and F. Hahn (1971). General Competitive Analysis (San Francisco: Holden Day).

Arrow, K. J. (1974). The Limits of Organizations (New York: Norton).

Askari, H. et al. (2009). New Issues in Islamic Finance and Economics (Singapore: John Wiley and Sons).

Askari, H. et al. (2010a). Globalization and Islamic Finance (Singapore: John Wiley and Sons).

Askari, H. et al. (2010b). The Stability of Islamic Finance (Singapore: John Wiley and Sons).

Askari, H. et al. (2012). Risk Sharing Finance: The Islamic Finance Alternative (Singapore: John Wiley and Sons).

Bakkali, S. (2017). "Risk Sharing in Contemporary Finance: Fish Perspective." PhD Dissertation, INCEIF, Kuala Lumpur, Malaysia.

Bartholomeu, D. J. (2008). God, Chance and Purpose (Cambridge: Cambridge University Press).

Bogle, J. C. (2012). The Clash of Cultures: Investment vs Speculation (Hoboken, New Jersey: John Wiley).

Brouwer, M. (2005). "Managing Uncertainty through Profit Sharing Contracts from Medieval Italy to Silicon Valley," Journal of Management and Governance, Vol. 9, pp. 237-755.

Chapra, M. U. (2007). "Challenges facing the Islamic financial industry," in M. K. Hassan and M. K. Lewis (eds.) Handbook of Islamic Banking (Cheltenham, UK: Edward Elgar), pp. 325-360.

Cizakca, M. (2011). Islamic Capitalism and Finance: Origins, Evolution and the Future (London: Edward Elgar).

Cizakca, M. (ed.) (2014). Islam and the Challenge of Western Capitalism (London: Edward Elgar).

Cowen, T. (1983). "The Rate of Return in General Equilibrium: A Critique," Journal of Post Keynesian Economics, Summer 1983, Vol. 5, pp. 608-617.

Epstein, G. A. (2005). Financializaton and the World Economy (Cheltenham, UK: Edward Elgar).

Evensky, J. (1989). "The Evolution of Adam Smith’s Views on Political Economy," History of Political Economy, Vol. 21, No. 1, pp. 123-145.

Evensky, J. (1993). "Ethics and the Invisible Hand," Journal of Economic Perspectives, Vol. 7, No. 2, pp. 197-205.

Evensky, J. (2011). "Adam Smith's Essentials: On Trust, Faith, and the Free Markets," Journal of the History of Economic Thought, Vol. 133, No. 2, pp. 249-268.

Fama, E. F. and M. C. Jensen (1983). "The Agency Problems and Residual Claims," Journal of Law and Economics, Vol. XXVI, pp. 327-349.

Fischel, W. (1933). "The Origin of Banking in Medieval Islam," Journal of the Royal Asiatic Society, pp. 339-352; 568-603. Also published in Islamic Culture, Vol. XIV. Cairo: Bureau of Compilation, Translation and Publication.

Graeber, D. (2011). Debt: The First 5,000 Years (London: Melville House).

Goitein, S. D. (1955). "The Cairo Ginza as a Source of the History of Muslim Civilization," Studia Islamica, Vol. 3, pp. 75-91.

Goitein, S. D. (1964). "Commercial and Family Partnerships in the Countries of Medieval Islam," Islamic Studies, Vol. 3, pp. 318-319.

Guiso, L. et al. (2005). "Trusting the stock market.” NBER Working Paper No. 11648 (Cambridge: MA: National Bureau of Economic Research).

Guiso, L., P. Sapienza and L. Zingales (2004). "The Role of Social Capital in Financial Development," The American Economic Review, Vol, 94. No, 3. pp. 526-556.

Habachy, S. (1962). "Property, Right, and Contract in Muslim law," Columbia Law Review, Vol. 62, No 3. 
Halaissos, M. and C. Bertaut (1995). "Why do so Few Hold Stocks?" The Economic Journal, Vol. 105, No. 432, pp. $1,110-1,129$.

Haneef, R. and A. Mirakhor (2014). "Islamic Finance: Legal and Institutional Challenges," ISRA International Journal of Islamic Finance, Vol. 6, No. 1, pp. 115-151.

Hassan, M. K. and M. K. Lewis (eds.) (2007). Handbook of Islamic Banking (Cheltenham, UK: Edward Elgar).

Hart, O. and B. Holmstrom (1987). "The theory of contracts," in Advances of Economic Theory, Fifth World Congress, T. Bewley (ed.) (Cambridge: Cambridge University Press).

Hellwig, M. (1998). "Banks, Markets, and Allocation on Risks in an Economy," Journal of Institutional and Theoretical Economics, Vol. 154, No. 1, pp. 328-345.

Hixson, W. F. (1991). A Matter of Interest (Montgomery, Alabama: E-Book Time).

Ibn Mandhoor (1984). Lisan Al-Arab (Qum, Iran: Nashr Adab).

Iqbal, Z. and A. Mirakhor (2011). An Introduction to Islamic Finance: Theory and Practice (Singapore: John Wiley and Sons). Jensen, M. C. and W. H. Meckling (1976). "Theory of the Firm: Managerial Behavior, Agency Costs and Ownership Structure," Journal of Financial Economics, Vol. 3, Issue 4, pp. 305-360.

Keynes, J. M. (1932). "Saving and Usury: A Symposium," Economic Journal, Vol. 42, No. 165, pp. 123-141. See also, Economic Journal, Vol. 41, No. 164.

Keynes, J. M. (1936). The General Theory of Employment, Interest, and Money (London: Macmillan; also St. Martin's Press, 1970).

Khadduri, M. (1977). "Property: Its relation to equality and freedom in accordance with Islamic law," in C. Wellman (ed.), Equality and Freedom: Past, Present, and Future (Franz Steiner, Verlag GmBH, Wiesbaden, Germany).

Kister, M. J. (1965). "The Market of the Prophet," Journal of the Economic and Social History of the Orient, Vol. 8, No. 3, pp. 272-276.

Knack, S. and P. Keefer (1997). "Does Social Capital have an Economic Payoff: A Cross-country Investigation," The Quarterly Journal of Economics, November, pp. 1,251-1,288.

Lane, E. W. (2003). An Arabic-English Lexicon (Lahore: Suhail Academy).

Lazzarato, M. (2011). The Making of the Indebted Man (Amsterdam: Agence litteraire Pierre Astier \& Associes) (Trans. Semiotext (e), 2012).

Lopez, R. S. (1976). The Commercial Revolution of the Middles Ages, 9500-1350 (Cambridge: Cambridge University Press).

Maghrebi, N., A. Mirakhor and Z. Iqbal (2016). Intermediate Islamic Finance (Singapore: John Wiley).

Mirakhor, A. (2010). "Whither Islamic Finance? Risk Sharing in an Age of Crisis." MPRA Paper No. 56341.

Mirakhor, A. and I. Zaidi (2007). "Profit-and-loss sharing contracts in Islamic finance," in Hassan, M. K. and M. K. Lewis (eds.), Handbook of Islamic Banking (Cheltenham, UK: Edward Elgar), pp. 49-63.

Mirakhor, A. and N. Krichene (2009). "The recent crisis: Lessons for Islamic finance," 2nd Public Lecture on Financial Policy and Stability, Islamic Financial Services Board, Kuala Lumpur, Malaysia.

Mirakhor, A. (1983). "Muslim contribution to economics," Paper presented at the Annual Meeting of the South-Western Economic Association, (London: Edward Elgar). March 1983, and reproduced in Murat Cizakca (ed.), 2014.

Mirakhor, A. (2009). "Islamic Economics and Finance: An Institutional Perspective," Journal of Economics and Management, Vol. 17, No. 1, pp. 31-37.

Mirakhor, A. and H. Askari (2010). Islam and the Path to Human and Economic Development (New York: Palgrave).

Mirakhor, A. and H. Askari (2017). Ideal Islamic Economy: An Introduction (New York: Palgrave Macmillan).

Mirakhor, A. and I. S. Hamid (2009). Islam and Development: The Institutional Framework (New York: Global Publications). Ng, Adam et al. (2015). Social Capital (New York: Palgrave Macmillan).

Power, D. and G. Epstein (2003). "Rentier income and financial crises," Working Paper No. 57 (Amherst, MA: Political Economy Research Institute, University of Massachusetts).

Rayner, S. E. (1991). The Theory of Contracts in Islamic Law (London: Graham and Trotman).

Sadr, S. K. (2016). The Economic System of The Early Islamic Period (New York: Palgrave Macmillan).

Sen, A. K. (1982). "Rational fools," in A. K. Sen (ed.), Choice, Welfare and Measurement (Cambridge, MA: MIT Press).

Sen, A. K. (1987). On Ethics and Economics (Oxford: Blackwell).

Sheng, A. (2009). From Asian to Global Financial Crisis (Cambridge: Cambridge University Press). 
Smith, A. (1776/1976). An Inquiry into the Nature and Causes of the Wealth of Nations. Edited in two volumes by W. B. Todd. See Vol. 2 of the Glasgow Edition of the Works and Correspondence of Adam Smith (Oxford: Clarendon Press).

Smith, A. (1976). The Theory of Moral Sentiments, D. D. Raphael and A. L. Manfie (eds.) (Oxford: Oxford University Press). Putri, S. (2017). "The relevance of risk sharing for modern economies: The case of Germany, 1933-1935," PhD Dissertation, INCEIF, Kuala Lumpur.

Tobin, J. (1984). "On the Efficiency of the Financial System," Lloyds Bank Review, No. 153, 1-15.

Udovitch, A. L. (1967). "Credit and a Means of Investment in Medieval Islamic trade," Journal of the American Oriental Society, Vol. 87, No. 3, July-September, pp. 260-264.

Udovitch, A. L. (1969). At the Origins of the Western Commenda: Islam, Israel, Byzantium? (Princeton, NJ: Princeton University Press), pp. 198-207.

Udovitch, A. L. (1970a). "Commercial techniques in early medieval Islamic trade," in D. Richards (ed.), Islam and the Trade of Asia. Philadelphia: University of Pennsylvania Press, pp. 37-62.

Udovitch, A. L. (1970b). Partnership and Profit in Medieval Islam (Princeton, NJ: Princeton University Press).

Walsh, V. (2000). "Smith after Sen," Review of Political Economy, Vol. 12, No. 1, pp. 5-25.

Weiss, W. M. (1989). The Bazaar: Markets and Merchants of the Islamic World (London: Thames and Hudson).

Zak, P. and S. Knack (2001). “Trust and Growth,” The Economic Journal, Vol. 111, April, pp. 295-321.

\section{Endnotes}

1. It should be noted that some scholars reject this real/financial dichotomy as artificial. In essence, they are two faces of the same coin: debt economy. See, e.g., Lazzarato (2011).

2. For a comprehensive discussion of financialization and its impact on the economy, see Abdulkarim, F. M. (2016). "Financialization of the Economy and Income Inequality in Selected OIC and OECD countries: The Role of Institutional Factors." PhD Dissertation, INCEIF, Kuala Lumpur, Malaysia.

3. It is worth noting that advances in information technology had expanded the traditional domain of commodities to a new commodity, data, which has become subject of exchange, trade and a major source of income for large corporation such as Google, Facebook, and other servers and social networks. They are making money off of a commodity that belongs to individuals. It could be expected at some point in the future, individuals may seek to benefit directly by claiming property rights of their own data which presently large corporations are explicitly using as a source of huge income.

4. For the ethical dimensions of Islamic finance, see Iqbal and Mirakhor (2017).

5. Some scholars have discussed the moral, emotional, and psychological costs of "debt slavery", or creditor-debtor relationship as "mechanism of exploitation and domination", or debt as a "capture", "predation", and "extraction" machine. See, e.g., Lazzarato (2011) and Hixson (1991). For a comprehensive coverage of the history of credit and debt, see Graeber (2011).

6. Contract theory developed in the 1980s. Two scholars who contributed to its development, Oliver Hart and Bengst Holmstrom, received the Nobel Prize for Economics in 2016.

7. It should also be noted that the debt system poses a serious threat to social solidarity in terms of its significant distributional impact stemming from the fact that it creates social conflict between the creditors (usually the rich) and the debtors (usually less economically able).

8. For an excellent and comprehensive discussion of the meaning and role of Al Bay' from a Fiqhi perspective, see Bakkali (2017).

9. For a review of this history, see Poitras, G. (2016). Equity Capital: From Ancient Partnerships to Modern Exchange Trade Funds Part I (New York: Routledge).

10. See Kister, 1965; Weiss, 1989; Cizakca, 2011, 2014. 